\title{
FRANTIŠEK WAIC - OLOMOUCKÝ SPOLUPRACOVNÍK VLADIMÍRA HELFERTA
}

Jedním z blízkých spolupracovníků Vladimíra Helferta při jeho úsilí o zkvalitnění hudební výchovy byl olomoucký pedagog František Waic. ${ }^{1}$ Ten své fundované názory na poslání hudebního vzdělávání dětí a mládeže systematicky a dlouhodobě promýšlel i ověřoval v praxi, čímž prripravil půdu $\mathrm{k}$ vědecké syntéze, kterou Helfert provedl prostřednictvím spisu Základy hudební výchovy na nehudebních školách (Paha 1930). Následující text Františka Waice představí, shrne jeho př́nos pro rozvoj hudební výchovy a pojedná o společné cestě Waice a Helferta k reformě předmětu uskutečněné ve třicátých letech minulého století.

1 ŠTĚDROŇ, Bohumír. Waic František. In Československý hudební slovník osob a institucí, Sv. 2, Praha: Státní hudební vydavatelství, 1965, s. 935-936; HELFERT, Vladimír. Prof. Frant. Waic. Letáková knižnice Cíl, č. 7, Olomouc, 1935 (dále Helfert); GREGOR, Vladimír. Z dopisů dr. Vladimíra Helferta Františku Waicovi. Časopis Vlastivědného spolku muzejního Olomouc, 1950, r. 59, s. 1-14 (dále Gregor 1); Týž. K výročí Františka Waice. Hudební výchova, 1950, r. 3, č. 5, s. 94; Týž. Kapitola z bojů za hudební výchovu (Hudební pedagog František Waic). Sborník praci pedagogického institutu v Ostravě 1962, s. 53-70 (dále Gregor 2); BARTOCHA, Rostislav. František Waic. Časopis Vlastivědného spolku muzejního Olomouc, 1940, r. 53, s. 103-105; Týž. Padesát let školské a veřejné práce prof. Frant. Waice. Věstnik pěvecký a hudební, 1935, r. 39, č. 6, s. 97-98 (dále Bartocha).

Na Katedře muzikologie FF UP v Olomouci byla obhájena diplomová práce Marie Skrottové: Působení Františka Waice v Olomouci, Olomouc, 2015. Zmínky o něm v souvislosti s jeho činností v Zábřehu na Moravě nalezneme v bakalářské práci Pavla Granzera, viz GRANZER, Pavel. Hudebni kultura v Zábřehu mezi lety 1840-1914. Bakalářská práce, FF UP v Olomouci, Olomouc, 2011. Kateřina Šanová autorkou písemné oborové práce, viz ŠANOVÁ, Kateřina. Pozůstalost Fr. Waice v depozitáři Vlastivědného muzea v Olomouci. Písemná oborová práce, FF UP v Olomouci, Olomouc, 2012. Pozůstalost Františka Waice je uložena ve Vlastivědném muzeu v Olomouci. Viz Hudební sbírka. Pozůstalost Františka Waice (1866-1939), 56 kartonů (dále Pozůstalost). 


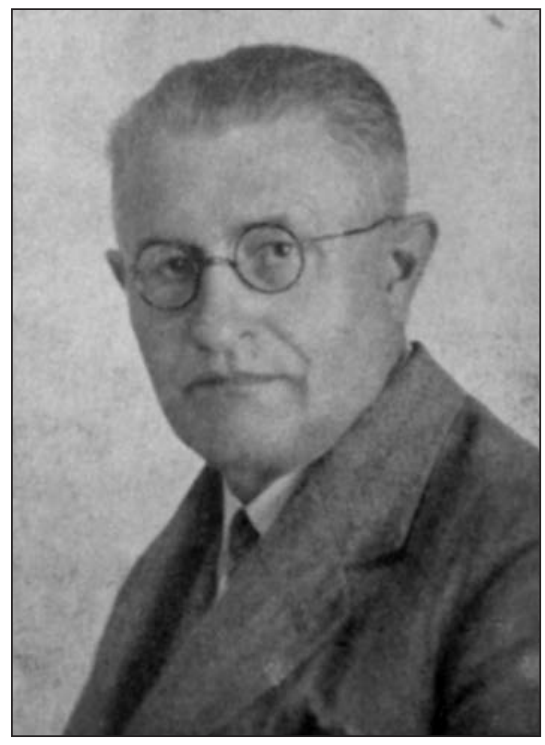

Obr. 1. František Waic.

I.

František Waic (21. 1. 1866 - 2. 11. 1939), vrstevník např́klad Romaina Rollanda či Erika Satieho, se narodil v roce premiéry Smetanovy Prodané nevěsty v Ouběnicích u Benešova. Jako potomek kantorského rodu odmalička zpíval v kostele. Studoval na reálném gymnáziu v Táboře (od roku 1878) a učitelském ústavu v Praze (1882-1885). Znalosti hudební teorie mu předali Jan Evangelista Zelinka a Arnošt Černý. Po získání způsobilosti k vyučování tělocviku (1900) a zpěvu (1902) vystř́ídal několik krátkodobých působišt' na obecných školách na Benešovsku a Lovosicku. Poté odešel na Moravu. Z Waicovy pětileté pedagogické činnosti v Zábřehu na Moravě (v letech 1901-1905) bývá připomínán jeho kontakt s mladým Karlem Boleslavem Jirákem či Václavem Kálikem.

Hlavním životním působištěm se Waicovi stala Olomouc. V letech 1905-1927 vyučoval na zdejší reálce zpěv a tělocvik a zároveň sborový zpěv na Hudební škole Žerotína (1908-1909). Činný zůstal i po odchodu do penze v roce 1927, nebot' pokračoval ve výuce zpěvu na učitelském ústavu, Zemské hospodyňské škole a Slovanském gymnáziu.

Waic byl výborným praktickým hudebníkem. Hrál na violu a disponoval zvučným basem, díky němuž se stal vyhledávaným členem mužských komorních pěveckých sdružení (Kvarteto, Okteto Žerotína v letech 1907-1909) i velkých těles (Pěvecké sdružení moravských učitelů, 1910-1931).

Neméně aktivní byl jako sbormistr a hudební organizátor. Ještě před př́ichodem na Moravu založil a vedl pěvecký kroužek ve Vetlé u Roudnice a Třebenické kvarteto. V Zábřehu na Moravě řídil sbor Občanské besedy a oživil tamější 
hudební život uspořádáním několika velkolepých koncertů. V Olomouci zastával funkci jednatele spolku Žerotín (1907-1909), v roce 1921 působil jako předseda Pěveckého sdružení moravských učitelů, od roku 1927 řídil sbor Slovanského gymnázia a v období 1929-1939 vedl padesátičlenný Pěvecký kroužek Československé obce legionářské v Olomouci. Je důležité zdůraznit, že Waic akcentoval ve své dramaturgii české moderní autory, čímž se podílel na propagaci soudobé hudby. V neposlední řadě rovněž pořídil několik úprav lidových písní.

Rozsáhlé bylo Waicovo odborné dílo. Z několikastránkových publikací hudebně pedagogického, didaktického a metodického rázu, většinou vydaných vlastním nákladem, stojí za zmínku: O reformě výchovy hudební zpěvem (Olomouc 1913), Škola intonační na podkladě národnich pisni slovanských pro školy měštanské a střední (Zábřeh 1913), Řikanky lidové pro tř́ibení zřetelné výslovnosti (Zábřeh 1913), O naši státní hymně (Zábřeh 1919), Šetřme hlasu (Zábř̀h 1923), Intonačni tabulky (Olomouc 1923), Zlidověni hudby (Olomouc 1923), Lidová výchova zpěvem a hudbou (Česká osvěta 1926), Nové diagramy $k$ vyučování intonace metodou tonální (Brno 1926), O směru moderní výchovy hudebni (Praha 1929), Estetický rozbor písně Kde domov můj (Olomouc 1934), Pro národní písen̆ (Olomouc 1935), Pěvecká čitanka (Olomouc 1935), Vzpomínka na A. Petzolda (Olomouc 1936) a Všeobecná přirozená hudební vloha (Olomouc 1937).

Po příchodu do Olomouce začal Waic rovněž recenzovat místní hudební život a referoval také o zahraničních koncertních cestách PSMU. Své články uveřejňoval - mnohdy pod šifrou „vk“ - v olomouckých Selských listech a Našinci, dále v Československém deníku, Moravském večerniku, v pražské Tribuně a Národni politice. Svými texty o hudební výchově a sborovém zpěvu přispíval do Akordeonu, Dalibora, Helferových Hudebnich rozhledů, Střední školy a Věstníku pěveckého a hudebního.

Waicovu životní energii a společenskou angažovanost dokumentují legitimace vážící se k členství v mnoha hudebních, kulturních či sportovních organizacích. Byl členem Foerstrovy společnosti, Pěvecké obce československé, Společnosti Leoše Janáčka, Spolku pro postavení Smetanova domu, olomouckého odboru Ústředního spolku československých profesorů, Umělecké besedy, Společnosti pro současnou kulturu Olomouce, Klubu přátel umění, Družstva českého národního divadla v Brně, Družstva českého divadla v Olomouci, Národní jednoty v Olomouci, Spolku zlatého kříže pro zemi moravskoslezskou, Radiosvazu československého, Klubu československých turistů, Československého červeného křřže v Olomouci, Československé obce sokolské či Spolku pro chov klusáckých a dostihových koní na Moravě. ${ }^{2}$

Stal se nositelem zlaté medaile Pěvecké obce československé. Zemřel v Olomouci.

2 Pozůstalost, karton 1. 
II.

Hlavním oborem působnosti Františka Waice byl zpěv. Věnoval se mu jako pedagog, interpret i sbormistr. Zvučný bas jej přivedl nejen do elitního Pěveckého sdružení moravských učitelů, ale např́íklad i k partu Šimona v Haydnově oratoriu Čtvero ročnich počasí 25 . dubna 1909 v Olomouci. ${ }^{3}$ Dá se předpokládat, že Waic se dokonale obeznámil s domácí literaturou z oblasti české metodiky zpěvu (František Pivoda, Jan Hejda, Roman Nejedlý ad.). Přesto se v této oblasti i nadále vzdělával. Absolvoval četné kurzy pro učitele, například kurz chorálu (v Praze v roce 1910) a zejména intonační kurz u Němce Maxe Battkeho (Praha 1912). Waic se stal prvním propagátorem jeho metody „Primavista“ na Moravě, když roku 1913 v Olomouci uspořádal dvaatřicetihodinový kurz intonace. Tuto metodu posléze adaptoval na domácí podmínky (podobně jako Stanislav Jiránek nebo Adolf Cmíral) tak, že ji propojil se zaužívanou intonací za pomocí intervalů českých lidových písní. Své závěry pak publikoval ve dvoudílné Škole intonační na podkladě národnich písni slovanských pro školy měštanské a středni (Zábřeh na Moravě 1913). Oproti svým kolegům však používal lidové písně nejen pro vybavení stupnicových řad a trojzvuků, ale i pro učení intervalů. Kvalitu učebnice ocenil např́klad Josef Bohuslav Foerster těmito slovy: „Vaše 'Škola intonačni' [...] je výborný spisek, znamenitá pomůcka vyučovací, dílo výtečného pedagoga, jenž pracoval na základě dlouhé zkušenosti praktické a pak: srdce a duší. A škola Vaše má $i$ vzácnou přednost původnosti. Až bude vydán i II. dill, jsem jist, že se chopi Vaši práce každý učitel zpěvu s největši radostí a více: docilí jistě snadným zpưsobem nejlepšich výsledků [...].“4

Zmíněnou publikaci Waic využíval při výuce na státní reálce, ale také ve své soukromé intonační škole pro mládež i dospělé, kterou v Olomouci v roce 1913 založil. Waicova metoda je dodnes považována za rovnocennou paralelu intonačních metod Adolfa Cmírala, Oldřicha Hilmery, Stanislava Jiránka či Františka Spilky, které předznamenávají dílo Františka Lýska a Ladislava Daniela. Mezi didaktickými pomůckami získala pevné místo rovněž Waicova intonační tabulka. ${ }^{5}$

Jako středoškolský profesor sledoval František Waic soudobé trendy v oblasti hudebního vzdělání. Zejména reformní hnutí v Německu a Rakousku, jež bylo deklarováno během sjezdů v Berlíně (od roku 1903) a ve Vídni (1911). Stejně jako v zahraničí i u nás existovala celá řada učitelů (S. Jiránek, A. Cmíral či F. Spilka), kteří nepochybovali o tom, že hudební výchova - tehdy označovaná jako zpěv - by měla radikálně změnit svou podobu. Její výuka totiž často tkvěla

3 JARKA, Václav Hanno - VYBÍRAL, Bohuš - TOMEK, Ferdinand. Padesát let olomouckého „Žerotína" 1880-1930. Olomouc, 1931, s. 50.

4 Dopis J. B. Foerstra F. Waicovi psaný v Praze 8. 2. 1913. Pozůstalost, karton 6, viz také Gregor 1, op. cit, s. 2.

5 O intonačních metodách více viz: SEDLÁK, František a kolektiv. Nové cesty hudební výchovy na základní škole, Praha: Státní pedagogické nakladetství, 1977, nebo GREGOR, Vladimír - SEDLICKÝ, Tibor. Déjiny hudebni výchovy v českých zemích a na Slovensku, Praha: Editio Supraphon, 1990. 


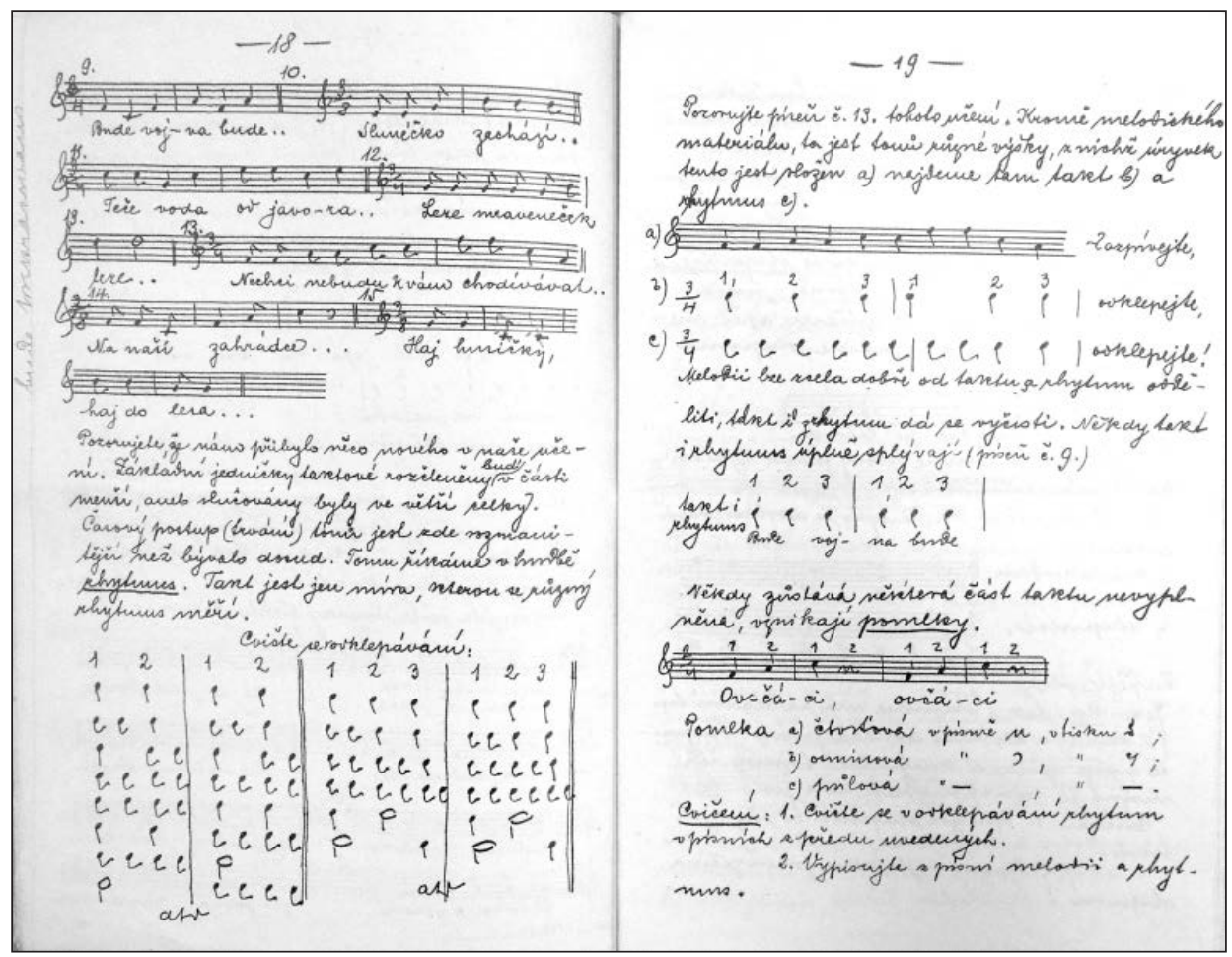

Obr. 2. František Waic: Intonačni škola, Olomouc 1910. Ukázka konkrétních cvičení.

v rukou málo kvalifikovaných pedagogů, kteří prošli jen povinným kurzem, a tudíž nedovedli správně pečovat o hlas dětí a mládeže, nevolili vhodné písně apod. Stále častěji se také začalo hovořit o tom, že dětem a mládeži na školách chybí obecnějš́i umělecká výchova, že nejsou náležitě vedeny k estetickému vnímání hudby, k poučené recepci děl, k porozumění jejich obsahu za přihlédnutí ke své psychologické vyspělosti apod. ${ }^{6}$ Svou roli přirozeně také sehrál vynález gramofonu a zahájení vysílání rozhlasu, takže do popředí se začala prosazovat recepce na úkor reprodukce.

Waic prosazoval nový obsah hodin zpěvu. Jejich ústřední náplň shledával v rozvoji hlasových dovedností a nácviku lidových písní. V nich spatřoval výchovný význam. Kritizoval však dril uplatňovaný při zpěvu zpaměti a neznalost not. O jeho dalších názorech se lze dočíst ve spise $O$ reformě výchovy hudebni zpěvem (Olomouc 1913).

6 Waic byl v písemném styku např. s Emilem Axmanem, Otakarem Jeremiášem, Otakarem Ostrčilem, Josefem Jiránkem, Stanislavem Jiránkem, Oldřichem Hilmerou nebo Adolfem Cmíralem. Pozůstalost, karton 6. 
Výrazný impuls do Waicovy pedagogické praxe přišel již v roce 1909, kdy veřejně zkritizoval konzervatismus repertoáru, úpadek dramaturgie i způsob umělecké práce olomouckého Žerotína a spolek opustil. ${ }^{7} \mathrm{O}$ rok později vstoupil do PSMU ř́zeného Ferdinandem Vachem. Nejen vysoká umělecká prestiž tohoto tělesa, ale také způsob Vachovy práce a cesta k interpretaci moderní sborové tvorby přiměly Waice k promýšlení komplexního pojetí hudební výchovy. Uvědomil si totiž, že $\mathrm{k}$ tomu, aby společnost dokázala náležitě ocenit význam uměleckých děl - v prŕípadě PSMU to byly např́íklad sbory V. Nováka, J. Suka, J. B. Foerstra či O. Ostrčila - musí na ně být připravena a k jejich pochopení soustavně vedena. Svým přesvědčením, že „,možno časem približiti široké vrstvy lidu dílům hudebním doby nejnovější a dob príšstích [...]"8 se v roce 1913 přiblížil názorům, které ve svých spisech O socializaci umèní (1903), Umèní a společnost (1907) a Umění a príroda v estetické výchově (1907) předložil O. Hostinský.

Hudební výchovu - ostatně tento termín razil Waic ještě před Vladimírem Helfertem - rozdělil na dvě hlavní složky: reprodukční a receptivní a své názory shrnul do třech článků publikovaných v letech 1919-1920: Zpěv v nové škole, K vývoji hudebni výchovy, zvláště na školách a Výchova tělesná a hudebni. ${ }^{9}$ Cestu k porozumění hudbě Waic spatřoval ve cvičení hudebního sluchu (a smyslu pro tonalitu, melodii, harmonii a rytmus) a $\mathrm{v}$ poučeném poslechu.

Již záhy po příchodu do Olomouce proto připravoval mládež k pochopení hudebních děl formou veřejných besed a proslovů. K nim např́klad patřila přednáška o Edvardu H. Griegovi v předvečer koncertu spolku Žerotín 16. listopadu $1907^{10}$ či 16. května 1909, kdy pro žáky před koncertem prostějovské Orlice představil rozbor Kř́žkovského sborů. ${ }^{11}$ Hudební besedu uspořádanou pro účastníky intonačního kurzu 2. července 1913, na níž zazněly lidové písně, sbory Foerstra a Josefa Holého, několik klavírních skladeb (Grieg a Dvořák) a Foerstrův melodram, lze považovat za jeden z prvních výchovných koncertů v Olomouci. ${ }^{12}$

Ve snaze o zlidovění hudby přijal Waic angažmá v Okresním osvětovém sboru, jenž pořádal lidové kurzy pro dospělé. V jejich rámci vystoupil nejen v Olomouci, ale také v Tišnově, Zábřehu na Moravě, Šumperku, Lipníku apod. V roce 1929 pro změnu přednášel pro Lidovýchovný ústav v Praze. ${ }^{13}$ Své názory na „lidový-

7 GREGOR, Vladimír. Památník pěvecko-hudebního spolku Žerotín v Olomouci 1880-1950, Praha, 1932 (dále Gregor 3), s. 25-26.

8 WAIC, František. O reformě výchovy hudebni zpěvem. Olomouc, 1913, s. 27, viz také Gregor 2, op. cit., s. 57.

9 WAIC, František. Zpěv v nové střední škole. Hudební revue, 1919, r. 12, č. 6 a 7; K vývoji hudební výchovy, zvláště na školách. Věstník ústřr. spolku učitelského na Moravě a ve Slez$s k u, 1920$, r. 17, č. 43-44, 15. 8. 1920; Výchova tělesná a hudební. Československý deník, 1920, 3. 4. 1920.

10 Viz Pozůstalost, karton 40, také Gregor 2, op. cit., s. 58.

11 Viz Pozůstalost, karton 40, také Gregor 2, op. cit., s. 58.

12 Viz Pozůstalost, karton 40, také Gregor 2, op. cit., s. 58.

13 Vyplývá to ze studia Pozůstalosti, dále z textu R. Bartochy, viz Bartocha, nebo V. Gregora, viz Gregor 2, op. cit., s. 66. 
chovu“ prezentoval v pojednání O zlidověni hudby (Olomouc 1923). Lidovýchovu považoval za pokračování hudební výchovy školské. Byl také přesvědčen, že další formou rozvoje hudebnosti dospělých může být jejich aktivní účast na spolkovém sborovém životě. Nově obrozeným hudebním spolkům adresoval svou Pěveckou čitanku (Olomouc 1935) nebo Kapitoly pro pěvecké spolky (nedatováno). Upřímně věřil, že hudba nepatř́ jen hudebně nadaným, ale všem.

Přestože Waic uznával účinky toho, co dnes nazýváme hudební výchovou funkcionální, domníval se, že hudebně vzdělanou společnost musí formovat především škola. Zaručoval však tehdejší systém hudební výuky dětí a mládeže dostatečně kvalitní a soustavné vzdělání? Specializovaná hudební výuka na hudebních školách, ve spolcích či u soukromých učitelů za žádných okolností nepokrývala mezery, které získávala středoškolská mládež absencí hudební výchovy $\mathrm{v}$ učebních osnovách. Tato skutečnost motivovala Waice v účasti na boji středoškolských hudebních pedagogů za povinnou a naukovou hudební výuku středoškolské mládeže na všech typech nehudebních škol. Pro tento účel Waic založil hudební sekci Ústř̌edního spolku českých profesorů v Praze. Absolvent střední školy měl být - dle Waicova názoru - dobrým sborovým pěvcem a měl rozumět hudbě stejně dobře jako literatuře. V učebních osnovách, které navrhl, neměly chybět výklady s ukázkami skladeb, hudební formy, estetika, hudební besedy či sborový zpěv se sluchovými cvičeními.

Právě při tomto úsilí se Waicova cesta protnula s obdobnými snahami Vladimíra Helferta.

III.

Osmapadesátiletý František Waic se osobně setkal se sedmatřicetiletým Vladimírem Helfertem (1886-1945) v roce 1923, kdy byl jako předseda PSMU pověřen prrípravou jeho Památníku a Helfert působil jako hlavní editor této publikace. ${ }^{14}$ Zájem o PSMU pak spojoval oba představitele i nadále, i když jejich další osobní kontakty a písemná korespondence se nadále týkaly především hudební výchovy. ${ }^{15}$

Spolupráce Helferta s Waicem byla založena na vztahu vědce a praktika. Oba a z rozdílných svých pozic dospěli k obdobným stanoviskům o smyslu a podobě hudebního vzdělání. Ty pak Helfert předložil veřejnosti ve svém spisu Základy hudebni výchovy na nehudebních školách (Praha 1930). ${ }^{16}$

14 O Vladimíru Helfertovi více viz POLEDŇÁK, Ivan. Helfert, Vladimír.[online]. [Cit. 201502-02]. Dostupné z: < http://www.ceskyhudebnislovnik.cz. Také PEČMAN, Rudolf. Vladimír Helfert. Brno: Nadace Universitas Masarykiana etc., 2003.

Viz Pozůstalost, karton 6. Zde se nachází 44 dopisů a 47 pohlednic od V. Helferta. Nejdůležitější z nich byly zveřejněny, viz Gregor 1, op. cit.

16 Dřívější názory V. Helferta na obsah předmětu hudební výchova viz HELFERT, Vladimír. Hudba na středních školách. Hudebni rozhledy 1924-1925, r. 1, s. 147-150, ale i další články z ročníků 1925-1926 a 1926-1927. 


\section{„HUDEBNÍ ROZHLEDY“}

REDAKCE:

BRNO, ZELNÝ TRH 8

BRNO. $24 . \bar{X} \cdot 924$.

Administrace: Brno, Ćeské ul, 52, Telefon 516-VIII

$\sim_{0}$

$$
\text { Varing pane/ropesone, }
$$

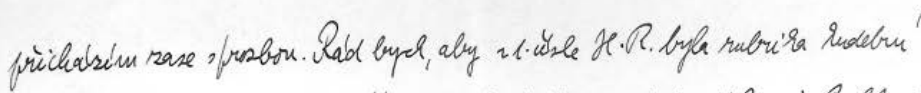

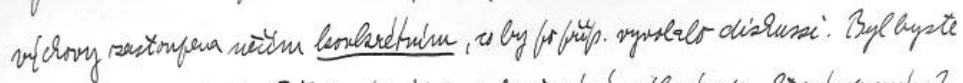

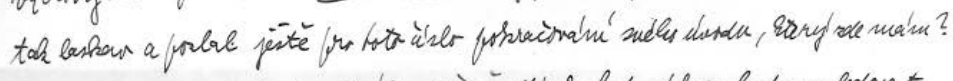



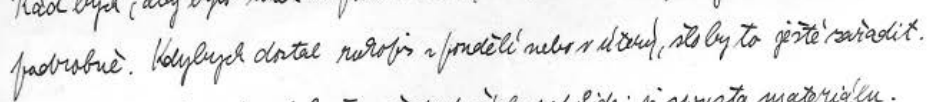

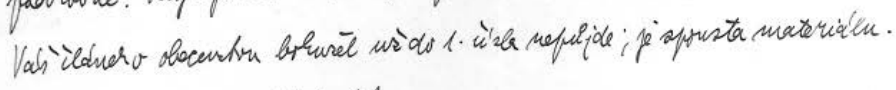
He piste a vebrocte sblit, s'?

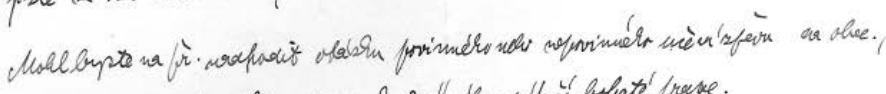

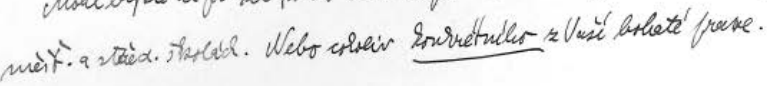

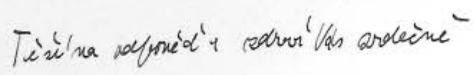



Obr. 3. Dopis Vladimíra Helferta Františku Waicovi z 24. 9. 1924, v němž jej vyzývá k napsání př́spěvku do svého časopisu.

To, za co oba společně bojovali, lze vyčíst z následujících Helfertových řádek adresovaných Waicovi: „Naše cíle jsou jiné a vyšší: Hudba jako součást všeob. vzdělání a jako prostředek výchovný. "17 V dalším dopise pak Helfert dodává: ,[... [ má-li hudební výchova dosáhnout svého cíle, to je prispivat $k$ výchově člo-

17 Dopis V. Helferta F. Waicovi psaný v Brně 4. 7. 1932. Pozůstalost, karton 6, viz také Gregor 1, op. cit., s. 6. 
věka, tvořit harmonickou osobnost a vytvářet hudební inteligenci a tím i př̀istí vnímavé obecenstvo, nesmí se zastavit na polovině cesty, musí jít právě do těch let, kdy vnímavost mladé duše pro uměni se obirá (sexuelni dospiváni).“18

Jedinou možností, jak dosáhnout výše zmíněných cílů, bylo uzákonit povinnou hudební výchovu na všech stupních a typech škol, tedy na školách národních, měšt’anských, středních a odborných, což by zajistilo nepřetržitou hudebně výchovnou linii od 6 do 18 let. V tomto ohledu Waic i Helfert vyvíjeli r̆adu aktivit. Seznamovali širší i odbornou veřejnost se svými názory prostřednictvím denního i odborného tisku (Akordeon, Hudebni rozhledy, Střední škola), působili v komisi pro hudební výchovu při Pěvecké obci československé a spolupracovali s Ministerstvem školství a osvěty. Museli však svou vizi také obhajovat proti početné skupině hudebních pedagogů-praktiků. Helfert je nazýval „,echaři“, nebot’ prosazovali pouze praktickou stránku výchovy a $\mathrm{v}$ podstatě preferovali intonační dril na úkor dalších aktivit.

Od školního roku 1930-1931 se Helfertovým spolupracovníkům včetně Waice podařilo prosadit hudební výchovu jako předmět relativně povinný v prvním a druhém ročníku středních škol, $\mathrm{v}$ dalších letech bojovala námi pojednávaná dvojice v komisi pro nehudební školy v Pěvecké obci československé po boku Zdeňka Nejedlého, Dobroslava Orla, Václava Vosyky, Oldřicha Hilmery či Jaromíra Fialy o to, aby se stala hudební výchova v prvních dvou ročnících střední školy zcela povinnou a figurovala také ve vyšších ročnících těchto škol. Velkým úspěchem se stalo zavedení aprobačních zkoušek budoucích středoškolských pedagogů hudební výchovy před zkušebními komisemi na filozofických fakultách v roce 1932, čímž byla nadále garantována náležitá odbornost učitelů.

Kontakty Helferta s Waicem se vyvíjely i v dalších rovinách. Zásluhou Helferta se Waic stal mimořádným posluchačem hudební vědy v Brně (studoval zde v letech 1927-1933). Helfert dokonce připravoval Waicův přechod do Brna, kde se pro něj snažil získat místo na pokusné škole Chlupova semináře při vysoké škole pedagogické, na níž měl vést praktické semináře hudební výchovy. Toto místo však Waic nakonec nezískal, patrně z důvodu pokročilého věku. Jako lektor však prŕležitostně působil na učitelských kurzech pořádaných Helfertem a Vosykou. Jakou měla Waicova výuka podobu, vyplývá z následujících Helfertových pokynů: „Vaši hodinu si pak predstavuju tak, že byste učitelưm ukázal ony vybrané pisně, a to asi tak, že byste je rozdèlil nejprve podle textového obsahu, čeho se týkají, o každé malinko néco rekl. To by mohlo trvat asi tak 40 minut. Zbývajicich 20 minut by pak bylo na návod, jakým zpưsobem písně nacvičit. K tomu účelu byste nějakou vybral, podrobněji ji rozebral po textové stránce a hlavně po hudebni: rozsah, melodie, harmonická struktura, forma. A pak byste ukázal, jak ji intonačně nacvičit. Smysl těchto 20 minut by tedy byl ten, že by učitelé poznali,

18 Dopis V. Helferta F. Waicovi psaný v Brně 7. 10. 1932. Pozůstalost, karton 6, viz také Gregor 1, op. cit., s. 8-9. 
jak na takové písni mohou dètem ukázat nejen intonaci, nýbrž zároveň i přibližit základni otázky harmonie a formy." "19

K osobním kontaktům docházelo také v Olomouci, kam Helfert roku 1934 zajížděl kvůli vydávání kulturního měsíčníku Index. V téže době se Helfert stal lektorem Waicovy Pěvecké čitanky (Olomouc 1935), k níž poznamenal: „Velice mne Vaše nauka zajímala a mohu Vám $k$ ní jen poblahoprát. Je psána velmi instruktivně a př́stupně a myslím, že pro sbormistry to bude výborná př́ručka. [...] Vaše př́klady jsou velice vhodné a dodávaji Vaši práci zvláštni ceny. Vaše metoda, vycházet v základech hudby z lidové písně a Váš výběr je skutečně něco pozoruhodného. Můžete mit, pane profesore, skutečně radost. Sám se už těším, až věc bude v tisku. “20

U př́ležitosti padesátiletého výročí Waicovy veřejné činnosti o rok později pronesl Helfert slavnostní řeč, která následně vyšla tiskem. ${ }^{21}$ Kromě ohodnocení zásluh na poli hudebně pedagogickém se v ní autor vyznává také z obdivu některých rysů Waicovy osobnosti:

„Měl jsem štěstí úzce spolupracovati s profesorem Waicem. Mohu řici, že ve všech pracích byl mi vždy posilou zjev tohoto starého - mladého bojovníka pro ideály hudební výchovy. A měl by býti vzorem pro svou nezištnost a obětavost. Jak všem svým snahám výchovným věnuje všechno, jak se neleká žádné oběti, o tom bych mohl vyprávěti kapitoly.“22

Waic měl s Helfertem mnoho společného. Oba se patrně vyznačovali podobným temperamentem a vytrvalostí, s nimiž obhajovali své přesvědčení, byt' proti vůli většiny. O nekompromisnosti a neústupnosti Františka Waice svědčí jeho názorové spory, které vedl s hudebními pedagogy (s Antonínem Hromádkou či Jaroslavem Hradilem), ${ }^{23}$ hudebními kritiky a novináŕi (s kritikem deníku Pozor či Vladimírem Ambrosem) ${ }^{24}$ nebo některými členy spolku Žerotín. ${ }^{25} \mathrm{~V}$ nich nelze nevidět obdobu Helfertových půtek se Zdeňkem Nejedlým. V neposlední řadě oba pojil hluboký obdiv k osobnosti Ferdinanda Vacha či jejich aktivity v čele hudebních těles, Orchestrálního sdružení v př́ípadě Helfertově, nebo Pěveckého kroužku Československé obce legionářské v prŕípadě Waicově. Zdá se tedy, že během výletư do údolí řeky Bystřičky na Olomoucku, které společně podnikali, měli pořád o čem diskutovat...

19 Dopis V. Helferta F. Waicovi psaný v Brně 16. 10. 1933. Pozůstalost, karton 6, viz také Gregor, op. cit., s. 10.

20 Dopis V. Helferta F. Waicovi psaný v Brně 12. 11. 1934. Viz také Gregor 2, op. cit., s. 13-14.

21 Viz pozn. č. 1.

22 Helfert, op. cit., s. 14.

23 Viz Pozůstalost, karton 14.

24 Viz Pozůstalost, karton 14, dále viz vyjádření Vladimíra Ambrose. Viz SMETANA, Robert. O nový český hudebni život. Olomouc, 1947, s. 43.

Viz Gregor 3, op. cit., s. 25. 
Eva Vičarová (eva.vicarova@upol.cz), Katedra muzikologie, Filozofická fakulta, Univerzita Palackého, Olomouc.

\section{ABSTRACT \\ TO THE FRANTIŠEK WAIC -AN OLOMOUC COLLABORATOR OF VLADIMÍR HELFERT}

František Waic (1866-1939) was one of the foremost personalities in music in prewar Olomouc. His greatest importance is based on the stimuli provided for the teaching of music. His views on general as well as specialized music education of children, young people and adults prepared the ground for the scholarly synthesis expounded by Vladimír Helfert in his book (in Czech) Essentials of Music Education in Non-Music Schools (Prague 1930).

Waic was a precursor of Helfert in promoting a new content of "music education" and in application of principles of "socialization of art" in the spirit of Otakar Hostinský. They jointly fought for a new conception of music education. They wanted to make it a required subject in secondary schools and initiated higher demands on professional training of music teachers.

\section{Key words}

František Waic, Vladimír Helfert, Olomouc, music education, reform, 1930’s

\section{Bibliography}

BARTOCHA, Rostislav. František Waic. Časopis Vlastivědného spolku muzejního Olomouc, 1940, r. 53, s. 103-105.

BARTOCHA, Rostislav. Padesát let školské a veřejné práce prof. Frant. Waice. Věstník pěvecký a hudebni, 1935, r. 39, č. 6, s. 97-98.

GRANZER, Pavel. Hudebni kultura v Zábřehu mezi lety 1840-1914. Bakalářská práce, FF UP v Olomouci, Olomouc, 2011.

GREGOR, Vladimír. K výročí Františka Waice. Hudebni výchova, 1950, r. 3, č. 5, s. 94.

GREGOR, Vladimír. Kapitola z bojů za hudební výchovu (Hudební pedagog František Waic). Sborník praci pedagogického institutu v Ostravě 1962, s. 53-70.

GREGOR, Vladimír. Památník pěvecko-hudebniho spolku Žerotín v Olomouci 1880-1950, Praha, 1932, s. 25-26.

GREGOR, Vladimír. Z dopisů dr. Vladimíra Helferta Františku Waicovi. Časopis Vlastivědného spolku muzejniho Olomouc, 1950, r. 59, s. 1-14.

HELFERT, Vladimír. Hudba na středních školách. Hudebni rozhledy 1924-1925, r. 1, s. 147-150.

HELFERT, Vladimír. Základy hudební výchovy na nehudebních školách. Praha, 1930.

HELFERT, Vladimír. Prof. Frant. Waic. Letáková knižnice Cíl, č. 7, Olomouc, 1935.

JARKA, Václav Hanno - VYBÍRAL, Bohuš - TOMEK, Ferdinand. Padesát let olomouckého „Žerotina" 1880-1930. Olomouc, 1931, s. 50.

PEČMAN, Rudolf. Vladimír Helfert. Brno: Nadace Universitas Masarykiana etc., 2003.

POLEDŇÁK, Ivan. Helfert, Vladimír.[online]. [Cit. 2015-02-02]. Dostupné z:< http://www.ceskyhudebnislovnik.cz.

SEDLÁK, František a kolektiv. Nové cesty hudebni výchovy na základní škole, Praha: Státní pedagogické nakladetství, 1977, nebo GREGOR, Vladimír - SEDLICKÝ, Tibor. Dějiny hudební výchovy v českých zemích a na Slovensku, Praha: Editio Supraphon, 1990.

SMETANA, Robert. O nový český hudebni život. Olomouc, 1947, s. 43.

ŠANOVÁ, Kateřina. Pozůstalost Fr. Waice v depozitářri Vlastivědného muzea v Olomouci. Písemná oborová práce, FF UP v Olomouci, Olomouc, 2012. 
ŠTĚDROŇ, Bohumír. Waic František. In Československý hudební slovník osob a institucí, Sv. 2, Praha: Státní hudební vydavatelství, 1965, s. 935-936.

WAIC, František. K vývoji hudební výchovy, zvláště na školách. Věstník ústřr. spolku učitelského na Moravě a ve Slezsku, 1920, r. 17, č. 43-44, 15. 8. 1920.

WAIC, František. O reformě výchovy hudebni zpěvem. Olomouc, 1913.

WAIC, František. Výchova tělesná a hudební. Československý deník, 1920, 3. 4. 1920.

WAIC, František. Zpěv v nové střední škole. Hudební revue, 1919, r. 12, č. 6 a 7. 